\title{
Erratum to: Experiences of healing therapy in patients with irritable bowel syndrome and inflammatory bowel disease
}

\author{
Andrew Soundy ${ }^{1 *}$, Rhonda T. Lee ${ }^{2}$, Tom Kingstone ${ }^{2}$, Sukhdev Singh ${ }^{3}$, Pankaj R. Shah², Sandy Edwards ${ }^{5}$
} and Lesley Roberts ${ }^{4}$

Unfortunately, the original version of this article [1] contained an error. Sandy Edwards was not listed among the authors. The correct version can be found below.

Soundy, A. ${ }^{1}$, Lee, R T. ${ }^{2}$, Kingstone, T. ${ }^{2}$, Singh, S. ${ }^{3}$, Shah, P R. ${ }^{2}$, Edwards, $S^{5}$., Roberts, L. ${ }^{4}$

${ }^{1}$ School of Sport, Exercise and Rehabilitation Sciences, University of Birmingham, Birmingham B15 2TT, UK

${ }^{2}$ Integrated Medicine Department, Freshwinds Charity, Prospect Hall, 12 College Walk, Selly Oak, Birmingham B29 6LE, UK

${ }^{3}$ Department of Gastroenterology, Consultant in Gastroenterology, Good Hope Hospital, Sutton Coldfield, UK

${ }^{4}$ Primary Care Clinical Sciences, School of Health and Population Sciences, University of Birmingham, Edgbaston, Birmingham B15 2TT, UK

${ }^{5}$ Healer Member of The Healing Trust, UK

\begin{abstract}
Author details
'School of Sport, Exercise and Rehabilitation Sciences, University of Birmingham, Birmingham B15 2TT, UK. ${ }^{2}$ Integrated Medicine Department, Freshwinds Charity, Prospect Hall, 12 College Walk, Selly Oak, Birmingham B29 6LE, UK. ${ }^{3}$ Department of Gastroenterology, Consultant in

Gastroenterology, Good Hope Hospital, Sutton Coldfield, UK. ${ }^{4}$ Primary Care Clinical Sciences, School of Health and Population Sciences, University of Birmingham, Edgbaston, Birmingham B15 2TT, UK. ${ }^{5}$ Healer Member of The Healing Trust, Northampton, UK.
\end{abstract}

Received: 29 July 2015 Accepted: 29 July 2015

Published online: 15 September 2015

\section{Reference}

1. Soundy A, Lee RT, Kingstone T, Singh S, Shah PR, Roberts L. Experiences of healing therapy in patients with irritable bowel syndrome and inflammatory bowel disease. BMC Complement Altern Med. 2015;15:106.

\footnotetext{
* Correspondence: A.A.Soundy@bham.ac.uk

${ }^{1}$ School of Sport, Exercise and Rehabilitation Sciences, University of Birmingham, Birmingham B15 2TT, UK

Full list of author information is available at the end of the article
}

\section{Submit your next manuscript to BioMed Central and take full advantage of:}

- Convenient online submission

- Thorough peer review

- No space constraints or color figure charges

- Immediate publication on acceptance

- Inclusion in PubMed, CAS, Scopus and Google Scholar

- Research which is freely available for redistribution

Submit your manuscript at

www.biomedcentral.com/submit

() Biomed Central 